\title{
Entre o fechamento e a abertura: a trajetória do PC do B da guerrilha do Araguaia à Nova República (1974-1985). ${ }^{1}$
}

Jean Rodrigues Sales*

\begin{abstract}
Resumo:
O objetivo deste artigo é discutir a história do Partido Comunista do Brasil (PC do B) no período compreendido entre o final da guerrilha do Araguaia, em 1974, até a Nova República Brasileira, com a chegada de José Sarney à presidência da República, em 1985. A análise está voltada para o entendimento do processo de mudança na linha político-partidária, que procura adaptar-se ao processo de democratização pelo qual passava o Brasil.
\end{abstract}

Palavras-chave: Partido Comunista do Brasil (PC do B), Ditadura Militar, Nova República, Democratização.

O Partido Comunista do Brasil (PC do B) é um dos mais antigos partidos políticos brasileiros. Nascido em 1962, a partir de uma cisão no Partido Comunista Brasileiro (PCB), conta hoje com 45 anos de atividade política. Durante esse longo trajeto, o grupo passou por muitos percalços: sobreviveu ao período da última ditadura militar; à disputa ideológica com sua matriz, o PCB; à guerrilha do Araguaia, durante a qual dezenas de militantes foram assassinados; à concorrência de novas forças de esquerda no início dos anos 1980 e, principalmente, à crise do socialismo real que varreu do mapa a maioria dos partidos comunistas existentes no mundo. O PC do B, ao contrário, não apenas sobreviveu, como ampliou a sua participação política nos anos 1980 e 1990. Conseguiu espaço no movimento sindical e estudantil e tem eleito vereadores, prefeitos, deputados e senadores em todo o país. Além disso, em 2002, participou da coalizão que elegeu o presidente Luiz Inácio Lula da Silva. No primeiro mandato de Lula, um de seus dirigentes, Aldo Rebelo, ocupou a presidência da Câmara dos Deputados, o que por si só representa um dos poucos, se não o único, exemplo no mundo capitalista ocidental de um comunista a ocupar tal cargo.

Apesar dessas realizações, o partido foi relativamente pouco estudado e continua a merecer maiores pesquisas acadêmicas a seu respeito. ${ }^{3} \mathrm{Na}$ produção escrita sobre o grupo, os temas tratados dizem respeito principalmente à década de 1960 e à primeira metade dos anos 1970, o que corresponde ao período de seu nascimento, estruturação 
política e envolvimento na guerrilha do Araguaia. ${ }^{4}$ Além disso, grande parte dos livros a seu respeito é fruto de trabalhos jornalísticos ou documentos do próprio partido.

Este artigo pretende contribuir para o entendimento da história recente do PC do B ao tratar de sua atuação no período que compreende o final da guerrilha do Araguaia e a consolidação da Nova República. Essa fase da história partidária é marcada por profunda mudança das propostas do partido, que buscava adaptar-se à situação política que se configurou com o fim do regime militar. Para que essa mudança acontecesse, entretanto, o PC do B teve que lidar com uma série de debates, tanto interna, quanto publicamente. Escolhi discutir alguns temas que podem ajudar na compreensão da profunda transformação sofrida pelo agrupamento, que aos poucos vê o tema da revolução, tão marcante nas décadas de 1960 e 1970, ser substituído pelo debate acerca da democratização do país, central na década de 1980.

\section{Uma guerrilha, muitas interpretações}

Entre 1972 e 1974, o PC do B enfrentou o exército na região do Araguaia, sul do Pará. Os militares mobilizaram milhares de homens em três campanhas para conseguir derrotar definitivamente algumas dezenas de militantes. Esse episódio passou a ser ressaltado pelo partido como um evento fundamental, que demonstrara a sua fibra revolucionária. E, de fato, a guerrilha marcou a sua história de diversas formas. Para o interesse deste artigo, vale dizer que ela representa o auge de uma estratégia política que era traçada desde o início dos anos 1960, marcada pela proposta de enfrentamento armado do regime militar, e a superação desse caminho por uma atuação inserida no processo de democratização do país. ${ }^{5}$

Da morte dos guerrilheiros até o momento em que o partido admitiu que os combatentes do Araguaia tivessem tombado, haveria ainda um longo caminho a ser percorrido. Seja pelo duro impacto da derrota, seja pelas dúvidas a respeito do que realmente havia acontecido com os militantes - se haviam sido presos ou mortos -, somente em abril de 1976 a direção do PC do B admitiu que houvesse acontecido um "temporário retrocesso na guerrilha". Todavia ressaltava que a bandeira da "guerra popular", empunhada pelos combatentes, continuava válida e que a luta guerrilheira seria, com “...o exército popular, adestrado em mil batalhas, capaz de assestar golpes demolidores nas forças de reação e libertar a pátria dos seus piores inimigos”. 6 
Essa não era, contudo, a posição de todo o partido a respeito do significado da experiência guerrilheira. Um ano antes, já haviam se iniciado as discussões a este respeito e, até aquele momento - abril de 1976 -, não se chegara a um denominador comum. Em fevereiro, o Comitê Central (C.C.) reuniu-se e aprovou uma Carta circular, a qual deveria ser lida pelos militantes. Esta, embora não tratasse diretamente da questão do Araguaia, apontava que a principal tarefa do partido era resguardar suas fileiras da repressão e voltar-se para o trabalho junto às massas, o que soava como uma crítica implícita ao voluntarismo presente no episódio da guerrilha. ${ }^{7}$

Foi, porém, em uma reunião realizada em março de 1976 que apareceram as duas tendências que demarcariam território na discussão. De um lado, a posição defendida por Ângelo Arroyo, membro da Comissão Militar e um dos poucos sobreviventes da guerrilha, sistematizada no documento Um grande acontecimento na vida do país, segundo a qual a experiência teria sido "altamente positiva". 8 Outra posição era representada por Pedro Pomar" ${ }^{9}$, para quem, de uma maneira geral, o erro do Araguaia teria sido estratégico e não tático; político e militar, e não apenas militar. Nesse caminho, uma das principais falhas teria sido não perceber que aquela conjuntura era desfavorável para o desencadeamento da guerrilha e que, além disso, se começara um combate corpo a corpo contra o exército, quando se deveria, antes, ter havido um trabalho político com as massas. Assim, não havia

\footnotetext{
como fugir da amarga constatação: ao cessar a resistência organizada, ao não ter alcançado nenhum dos objetivos a que se propôs, a guerrilha, apesar dos resultados positivos apresentados, sofreu derrota completa e não temporária. Infelizmente, o CC tem de aceitar a dura verdade de que o resultado fundamental e mais geral da batalha heróica travada por nossos camaradas foi o revés. ${ }^{10}$
}

As duas posições eram inconciliáveis. Além de divergirem sobre os erros ou acertos da experiência do Araguaia, elas traziam consigo elementos para a política que o PC do B deveria seguir no futuro. Subjacente à interpretação de Arroio de que acontecera apenas um erro secundário, de preparação, estava a idéia de que o partido poderia continuar com a mesma tática que utilizara até o momento - agitação das massas e preparação clandestina da luta armada. Já para Pomar, na medida em que não teria conseguido nenhum dos seus objetivos, aquela experiência demonstrara uma total ineficácia, sendo necessário pensar novas formas de atuação.

O desfecho das divergências não se daria sem conflitos. Em setembro de 1976, foi publicado um artigo no jornal $A$ Classe Operária, que tentava fechar as discussões 
iniciadas na reunião de março: Gloriosa jornada de luta. A essência do texto, porém, longe de denunciar os possíveis erros cometidos pelo partido no Araguaia, exaltava aquela que teria sido uma façanha histórica.

O C.C. reuniu-se em dezembro de 1976 para tratar do problema do Araguaia. Na reunião, a maioria dos participantes argumentou que o texto Gloriosa jornada de luta não traduzia as discussões travadas anteriormente, sendo necessário levar o debate para o conjunto do partido e tentar fazer as mudanças políticas e ideológicas que a situação pedia. As discussões, contudo, não puderam seguir o curso proposto na reunião. A polícia conseguira interceptar o local onde ela acontecia e prender os seus participantes à medida que saíam. Nem todos, porém, tiveram a mesma sorte. Foram assassinados, na casa em que acontecia a reunião, Pedro Pomar e Ângelo Arroio, neste episódio que ficou conhecido como "massacre da Lapa". 11

A morte dos dirigentes não pôs fim ao debate sobre a guerrilha do Araguaia, que retornaria durante a realização da VII Conferência em 1979 e, principalmente, nos primeiros anos da década seguinte, quando ressurgiria em meio a uma grave crise interna enfrentada pelo PC do B.

\section{A incorporação da AP}

No início dos anos 1970, em pleno desenrolar da guerrilha do Araguaia, a Ação Popular (AP) incorporou-se ao PC do B. Esse evento constituiu-se em um dos mais importantes de sua história. No momento em que o partido estava organicamente debilitado em conseqüência das mortes dos militantes no Araguaia e com a perseguição sofrida nas cidades, a AP oxigenou as suas fileiras. Para se ter uma idéia do peso dessa adesão, no momento em que aderem ao PC do B, os militantes oriundos da AP passam a somar cerca de metade dos membros do Comitê Central do partido. ${ }^{12}$

A AP pode ser considerada uma das principais organizações de esquerda existentes no país no período anterior ao golpe, particularmente no setor estudantil. Por exemplo, entre 1961 e 1964, os três presidentes da União Nacional dos Estudantes (UNE) pertenciam à AP: Aldo Arantes, Vinicius Caldeira Brant e José Serra. Além do meio estudantil, a AP também teve inserção em movimentos de massa, o que se exemplifica por sua participação no Movimento de Educação de Base (MEB) patrocinado pelo Ministério da Educação, cujo objetivo era a alfabetização da população através do método desenvolvido por Paulo Freire. Esse trabalho ajudou a AP a 
desenvolver projetos com os camponeses, levando a organização a participar da fundação da Confederação Nacional dos Trabalhadores Agrícolas (Contag) em dezembro de 1963. Resultou ainda na entrada de líderes dos trabalhadores rurais na AP, como foi o caso de Manuel da Conceição, do Maranhão.

Não por acaso, em 1983, durante a realização do VI Congresso do PC do B, se reconheceu que a incorporação da AP foi um "reforço político e orgânico do partido, pelo grau de combatividade e nível político de grande número de quadros que haviam se formado nas difíceis condições de luta contra o fascismo. Esse reforço se deu em nível regional e no Comitê Central, na estruturação de 1975".13

A incorporação, apesar de positiva para o PC do B, deu-se com um intenso debate nas fileiras da Ação Popular, durante o qual muitos participantes desta organização deixaram a militância política. De certa forma, as discussões remontam a meados dos anos 1960, quando a AP assumiu a influência do maoísmo em suas formulações, levando-a, em seguida, a se proclamar marxista-leninista. Além disso, embora, em 17 de maio de 1973, o Comitê Central da então Ação Popular MarxistaLeninista (AP-ML) tenha divulgado a sua última circular com a indicação de que seus militantes aderissem ao PC do B, a AP-ML não chegou ao fim, pelo contrário, mantevese enquanto organização autônoma até o início dos anos $1980{ }^{14}$

A entrada dos militantes da AP-ML no PC do B deu-se de forma individual. $\mathrm{Ou}$ seja, não houve uma junção de organizações, o que, aliás, seria difícil diante da dura perseguição policial. Assim, os militantes incorporavam-se individualmente ao PC do $\mathrm{B}$, salvo no que diz respeito à sua direção, na qual alguns dirigentes da AP-ML entraram diretamente no Comitê Central do partido. A junção dos militantes com aqueles que já atuavam no PC do B aconteceu sem qualquer resistência por parte destes últimos. Seja pelas discussões que já haviam sido realizadas anteriormente, seja pela grande deficiência orgânica pela qual passava o PC do B, a chegada dos novos membros foi saudada como uma grande vitória para o partido. ${ }^{15}$

Durante muito tempo, a versão do PC do B sobre a incorporação da AP-ML, consubstanciada no livro de Aldo Arantes e Haroldo Lima, foi aceita sem grande questionamento. ${ }^{16}$ Recentemente, porém, alguns estudos têm questionado e criticado tal interpretação. A crítica, em geral, é de que Lima e Arantes escreveram uma história da AP a partir da ótica do PC do B. Em outras palavras, a história da AP seria apresentada como se ela seguisse um curso natural até a chegada ao PC do B. Nesse caminho, as várias correntes e disputas internas que tiveram lugar na organização seriam 
desqualificadas em nome daquela que se incorporou ao partido. Além disso, diferente do que pode indicar esse livro, a AP-ML manteve a sua estrutura até 1981, quando passou a atuar como tendência dentro do Partido dos Trabalhadores, vindo a dissolverse em seguida. ${ }^{17}$

\section{A VII Conferência e a nova política}

Logo após a derrota da guerrilha do Araguaia, ainda antes de o fato ter sido anunciado formalmente, o PC do B começou a dar os primeiros passos rumo a uma nova tática ancorada na defesa da volta das liberdades políticas no país. A data que marcou essa virada foi janeiro de 1975, quando o jornal $A$ classe operária anunciou as resoluções tomadas pelo Comitê Central que apontavam para a defesa de uma política que entraria para a história partidária como as três bandeiras: assembléia constituinte livremente eleita, abolição de todos os atos e leis de exceção e anistia geral. ${ }^{18}$

De 1975 até o final da década de 1970, a política do PC do B girou em torno da denúncia dos crimes praticados pela ditadura e da defesa das três bandeiras. O principal caminho seguido foi a utilização dos espaços de oposição possíveis dentro da ditadura, particularmente através da atuação no Movimento Democrático Brasileiro (MDB). Para o partido, mesmo que as eleições fossem em grande parte uma farsa criada pelos militares, também podiam se constituir em uma denúncia do regime militar a partir das urnas. Dessa forma, o PC do B pregava o voto em massa no MDB, salvo naqueles locais em que não existissem candidatos do partido ou quando estes tivessem uma postura próxima dos candidatos da Aliança Renovadora Nacional (Arena). Nesse caso, o voto deveria ser nulo ou branco. ${ }^{19}$

Outro tema que mobilizou particularmente o partido na segunda metade da década de 1970 foi a luta pela anistia. Para o PC do B, o fortalecimento desse movimento poderia levar os militares à derrota. Para isso, a mobilização deveria atrair variados setores da sociedade, principalmente os populares, até a conquista plena da liberdade política e a derrota do regime discricionário. Naquele momento, a bandeira da anistia significava "a liberação imediata dos presos políticos e a anulação das condenações baseadas na Lei de Segurança; volta dos exilados e banidos e recuperação dos direitos políticos, sociais e profissionais dos militantes cassados pelos atos institucionais". 20 
Apesar de as propostas do PC do B irem por um caminho que se afastava do enfrentamento armado com o regime militar, na prática, permanecia em seu interior uma tensão em torno da efetiva aceitação dessa nova bandeira. Isso transparece, por exemplo, na continuidade da defesa da luta armada como um caminho inevitável para a vitória dos trabalhadores. Nesse sentido, ao mesmo tempo em que levantava a proposta da redemocratização, o PC do B afirmava que "a bandeira levantada pelos guerrilheiros [do Araguaia] não só exprime com justeza e força os sentimentos e interesses dos camponeses, parcela considerável da população. Diz respeito também aos patriotas de todo o país. Acabará triunfando!". 21

Não é de estranhar que as mudanças pelas quais começa a passar o PC do B sofressem oposição ou suscitassem dúvidas em alguns setores partidários. O partido havia sofrido uma dura derrota no Araguaia, que foi agravada pelo massacre da Lapa. Parte significativa de seus dirigentes estava exilada no exterior, enquanto muitos outros estavam presos no Brasil ou com atuação dispersa diante da dura perseguição sofrida pelo aparato repressivo. Nessa situação, era natural que divergências surgissem diante das mudanças políticas significativas pelas quais passavam o partido e o Brasil. Foi durante a realização de sua VII Conferência que o PC do B tentou equacionar os problemas internos e aglutinar os militantes em torno de uma nova linha política.

A VII Conferência foi realizada em Tirana, capital da Romênia, e contou com a participação dos dirigentes e militantes que estavam no exterior e de alguns que conseguiram sair do país clandestinamente para o encontro. O documento final aprovado na reunião apontou o caminho que deveria ser seguido pelos militantes em sua luta contra a ditadura militar. Na situação que se abria com a chegada do general João Batista Figueiredo à presidência, a política do $\mathrm{PC}$ do $\mathrm{B}$ deveria consistir em:

1) Defender firmemente as três palavras-de-ordem: abolição total e imediata de todos os atos e leis arbitrárias; anistia geral e irrestrita; e convocação, por um governo provisório democrático, de uma Constituinte livremente eleita.

2) Dar maior ênfase à conquista da liberdade política mais completa possível, considerando ser, precisamente este, o conteúdo das três palavras-de-ordem acima referidas. É necessário ir conquistando na prática as liberdades, como o direito de greve, de organização, de reunião, sem esperar que o regime atual desapareça de todo.

3) Desenvolver a luta pelas reivindicações mais sentidas das massas das cidades e do campo, esforçando-se para que ela adquira caráter político aberto; a partir do nível de compreensão das massas.

4) Desenvolver igualmente a luta contra o entreguismo e a espoliação do país pelo capital estrangeiro, também das dívidas externas.

5) Considerar como alvo principal do ataque das forças populares, democráticas e antiditatoriais, o regime militar e o governo de Figueiredo. Desmascarar intransigentemente todas as manobras do governo, com vista a seu completo isolamento e sua derrota. 
6) Unir as mais amplas forças políticas sociais em torno de bandeiras democráticas e populares, a fim de travar a luta contra o governo e o regime que ele representa. Propugnar a organização de uma ampla frente democrática em escala nacional, que agrupe todas as forças de oposição, e trabalhar pela sua concretização. Dentro dela, contribuir para articular e fortalecer a oposição popular como seu núcleo mais ativo e combater todas as restrições ao crescimento do movimento de massas ou as discriminações, tendo em vista unir a classe operária e despertar para a luta as grandes massas camponesas.

7) Opor-se à conciliação com o governo. Isolar os elementos conciliadores, como os revisionistas prestistas.

8) Pôr em prática todas as formas de luta e de organização cabíveis na situação presente, incentivando aquelas que facilitem o engajamento em ampla escala e a mobilização de massas; conduzindo assim à elevação do nível de sua consciência política, organização e combatividade.

9) Destacar em sua propaganda a palavra-de-ordem, conquista da democracia popular - uma vez alcançado o objetivo tático imediato - visando a afirmá-lo como o regime capaz de resolver os graves problemas que o país enfrenta.

A $7^{\text {a }}$ Conferência Nacional aprova o Manifesto à $\mathrm{Nação}^{22}$ no qual o Partido define sua opinião sobre a situação atual e chama o povo à luta para conquistar a liberdade política e alcançar a democracia popular. ${ }^{23}$

Além do novo posicionamento político do partido, o documento volta a tratar da temática relativa à guerrilha. Sobre a questão da luta armada de uma forma geral, mesmo no momento em que busca a redemocratização e a inserção nos movimentos sociais, o partido reafirma que ela é "fundamental e decisiva e para a política partidária”, uma vez que os interesses das classes populares só poderiam ser alcançados pelo "intermédio da revolução violenta". Sobre a experiência do Araguaia, o texto indicou o documento "Gloriosa jornada de luta”, de Ângelo Arroio, como ponto de partida para um exame da problemática da luta armada à luz das lições decorrentes da luta no Sul do Pará e das modificações que o país sofreu. A sistematização do problema deveria resultar em um documento a ser apresentado em tempo oportuno ao conjunto do partido. $^{24}$

Cabe lembrar, conforme apontamos acima, que, em meados da década de 1970, já haviam surgido divergências em torno da interpretação de Ângelo Arroio, cujo principal representante fora Pedro Pomar. A discussão foi truncada com a morte e prisão de vários dirigentes no massacre da Lapa. O documento final da VII Conferência não faz menção a tais divergências e elegeu o documento de Arroio como ponto de partida para a elaboração de uma resolução definitiva sobre a questão. Aos olhos de muitos militantes, a direção do PC do B cometera um grave erro ao não deixar transparecer os problemas internos relativos à guerrilha do Araguaia. Essas divergências, juntamente com as profundas modificações sofridas pela política partidária no início da década de 1980, levaram o PC do B a sofrer a maior crise interna de sua história. 


\section{A crise interna: organização, internacionalismo e abertura política}

O historiador Michel Dreyfus fez uma análise das diversas dissidências sofridas pelo Partido Comunista Francês no decorrer de sua história. Para o autor, apesar de parecerem desordenadas, as cisões, vistas em seu conjunto, revelam certa lógica de funcionamento dos partidos comunistas, que apresentam uma característica marcante: as divergências internas são breves e terminam com um rompimento brutal entre os protagonistas do debate. A brevidade de uma oposição interna relaciona-se com a implacável repressão exercida pela direção partidária. Uma oposição apenas tímida às diretrizes centrais pode ser aceita por algum tempo, mas logo terá que se adaptar à linha do partido. Quanto ao rompimento, costuma ser violento e definitivo. Militantes que atuaram anos em conjunto se afastam como se não houvesse traços do trabalho em comum. $^{25}$

A análise de Dreyfus, em que pesem as diferenças entre o comunismo brasileiro e o francês, ajuda no entendimento da história do PC do B. Este, ele próprio fruto de uma cisão no interior do PCB, já havia sofrido duas divisões entre 1966 e 1967, das quais surgiram o Partido Comunista do Brasil - Ala Vermelha (PC do B - AV) e o Partido Comunista Revolucionário (PCR). Nesses casos, as divergências relacionavamse às formas de luta que deveriam ser utilizadas contra a ditadura militar, em um momento no qual as esquerdas partiam para o combate armado contra os militares. Mais uma vez, agora entre 1979 e 1980, muitos militantes foram expulsos do partido. As motivações e interpretações dos que ficaram e dos que saíram são antagônicas. O que resta em comum é a dinâmica de funcionamento dos partidos comunistas da qual tratou Dreyfus.

A crise interna pela qual passou o PC do B no final dos anos 1970 e início dos anos 1980 esteve relacionada, de maneira imediata, às divergências sobre as resoluções da VII Conferência. Entretanto, ao se analisar de perto, verifica-se que dela fazem parte discussões mais amplas sobre as mudanças da política partidária no período final da ditadura militar. Ou seja, no momento em que se abre o debate sobre o rumo a ser seguido diante da abertura política, que certamente deveria ser diferente da política adotada até então, eclodiram desacordos que, incrementados pela tradição da impossibilidade da permanência de divergências internas, redundaram em uma cisão. 
Os principais protagonistas dos debates foram o Comitê Central do partido, o Comitê Regional Estrutura 1 de São Paulo ${ }^{26}$ e o Comitê Regional da Bahia (C.R.). Os problemas vieram à tona logo após a realização da VII Conferência, quando militantes, descontentes com a forma como foi realizado o encontro e com as suas resoluções, passaram a se posicionar criticamente nas instâncias partidárias. Isso ocorreu inicialmente em reuniões e, em seguida, através de documentos. Em dezembro de 1979, o C.R. baiano fez circular um texto no qual apresentava os motivos do descontentamento. Em primeiro lugar, criticava a Conferência por ter adotado o documento Gloriosa jornada de luta sem considerar que, desde 1974, havia divergências no C.C. sobre a guerrilha do Araguaia. Além disso, condenava a reunião por ela ter se limitado a "afirmar, aos seus participantes, que todas as outras opiniões sobre o Araguaia continham desvios e que no fundo negavam a necessidade da luta armada". ${ }^{27}$ Outra crítica levantada foi contra a resolução que abandonou o legado teórico de Mao Tse-tung e as ligações com a China, ${ }^{28}$ sem qualquer esclarecimento ou discussão dos motivos para a nova postura em relação aos chineses. Em janeiro de 1980, o C.R. da Bahia resumiu parte de suas divergências. Afirmou que o C.C. não admitia os erros cometidos e, quando o fazia, procurava resolvê-los de forma brusca e superficial, sem se aprofundar nas discussões. Por exemplo, afirmavam os dirigentes baianos que

\footnotetext{
não se discute o Araguaia aberta e profundamente e não se reconhecem em profundidade os seus prováveis erros, mas não se pretende repetir a experiência tal e qual, pelo menos agora; repudiase brusca e radicalmente o pensamento de Mao [Tse-Tung], como se nunca o tivéssemos absorvido; tenta-se mostrar como nunca assumimos as concepções da política externa chinesa, sem adotar uma postura autocrítica e sem que se diga uma linha sobre a nossa omissão em criticá-la... $^{29}$
}

O posicionamento da "Estrutura 1 de São Paulo" é bastante próximo daquele apresentado pelo C.R. da Bahia. Em linhas gerais, questiona o funcionamento do partido, que não estaria dando espaço para a discussão das divergências e havia, em uma Conferência pouco representativa, tomado medidas que modificavam a estratégia político-partidária. Diante das divergências, tanto o C.R. da Bahia quanto a Estrutura 1 propõem a convocação de um congresso para que todos os problemas fossem debatidos.

O Comitê Central não tardou a se pronunciar sobre a polêmica. Em março de 1980, os dirigentes reuniram-se e elaboraram um longo documento sobre a crise interna. O texto rebate ponto a ponto as propostas da Estrutura 1 de São Paulo e do C.R. da Bahia. De uma maneira geral, rechaça as críticas à organização partidária, defende a 
legitimidade da VII Conferência e, nesse sentido, as suas resoluções sobre a tática do partido, a guerrilha do Araguaia e as divergências com o Partido Comunista Chinês. Sobre a necessidade da realização de um congresso, o C.C. afirma que este somente seria convocado após o cumprimento de uma série de premissas, como a estruturação sólida do partido em todas as suas instâncias e a discussão aprofundada das decisões da VII Conferência por parte de todos os militantes. ${ }^{30}$

A direção do $\mathrm{PC}$ do $\mathrm{B}$ também adotou algumas resoluções para resolver as divergências internas: a rejeição completa dos documentos que foram escritos pela Estrutura 1 e pelo C.R. da Bahia, que feriam os estatutos partidários e eram "nitidamente antipartido"; a elaboração de um chamamento ao partido para lutar contra toda atividade desagregadora por parte desses organismos e militantes; a advertência aos setores do partido em São Paulo e na Bahia, exigindo que cessassem as atividades "antipartido", respeitando e aplicando as resoluções dos órgãos dirigentes. ${ }^{31}$

Os militantes que estavam em desacordo com o C.C. não aceitaram as resoluções sobre os impasses internos e insistiam nos principais pontos da polêmica: problemas de funcionamento partidário, com uma excessiva centralização de poder nas mãos do C.C.; fragilidade do embasamento teórico diante da nova conjuntura política; avaliação insuficiente da experiência do Araguaia; falta de esclarecimento sobre as críticas repentinas ao pensamento de Mao Tse-tung e, enfim, convicção de que somente a convocação do congresso poderia resolver os impasses internos.

Diante da recusa dos oposicionistas em aceitar a orientação da direção do partido, o C.C. interveio nos Comitês Regionais de São Paulo e Bahia, dissolvendo-os e indicando um assistente do Comitê Central para reestruturá-los. ${ }^{32}$ A Estrutura 1 de São Paulo não aceitou as decisões relativas a sua destituição e reiterou que não via legitimidade no C.C. ou na VII Conferência, passando a trabalhar pela organização de um congresso, independente do posicionamento da direção oficial do PC do B. ${ }^{33}$ Diante do impasse interno, muitos dos militantes que divergiam da direção do PC do B passaram a fazer o debate fora da estrutura partidária, o que teve início em 1979. Nessa data, foi publicado no jornal Movimento o documento conhecido como Carta de Pomar, na qual o dirigente expunha suas idéias críticas em relação à guerrilha do Araguaia. A publicação deste documento em um jornal que, mesmo próximo ao PC do B, não era seu veículo oficial abriu discussões públicas sobre as divergências internas do partido. ${ }^{34}$

Como em outros momentos da história dos partidos comunistas, seguindo aquela tradição apontada por Michel Dreyfus, as divergências chegaram ao ponto em que não 
foi possível a permanência das divergências dentro do partido, o que levou à cisão. $\mathrm{O}$ rompimento foi brutal, violento, não faltando ofensas pessoais e insinuações, de ambos os lados, sobre o comportamento dos militantes diante das torturas sofridas na prisão. Como também aponta Dreyfus, militantes que atuaram juntos durante décadas passaram, por muitos anos, a se tratar como inimigos inconciliáveis. Muitos dos envolvidos nas divergências foram expulsos, outros acabaram abandonando a militância. ${ }^{35}$

Parte daqueles que saíram do PC do B criou um outro agrupamento político, o Partido Revolucionário Comunista (PRC). A novidade trazida pela nova legenda foi a análise de que, no início da década de 1980, não seria prudente atuar de forma aberta, pois ainda haveria riscos de retrocesso na abertura política. Propunha, assim, uma dupla atuação: uma enquanto partido clandestino, de vanguarda, seguindo a tradição leninista; e outra como tendência dentro do Partido dos Trabalhadores, visto então como uma frente política progressista de luta contra a ditadura. O PRC teve vida efêmera e, em meados dos anos 1980, os seus militantes acabaram por aderir efetivamente ao PT.

A cisão marcou a história do PC do B. Por cerca de dois anos, o partido debateuse em intensa polêmica interna e externa, o que lhe trouxe a perda de muitos militantes e dirigentes, sobretudo na Bahia, no Rio de Janeiro e em São Paulo. Provavelmente as conseqüências não foram maiores porque, no início dos anos 1980, o PC do B experimentou relativo crescimento, conseqüência de sua presença no "Movimento Contra a Carestia", nas Oposições Sindicais do ABC paulista, entre outros movimentos sociais que marcaram o período. ${ }^{36}$ Vista em retrospectiva, a cisão continua a suscitar polêmica entre seus participantes. Para os que permaneceram no partido, os dissidentes cometeram erros ao não se enquadrarem nas normas estatutárias e foram expulsos não exatamente por suas idéias, mas por terem descumprido as regras internas. ${ }^{37}$ Já aqueles $^{2}$ que saíram do PC do B apontam que o Comitê Central usou expedientes administrativos para sufocar uma discussão profunda, que questionava a política e a organização interna do partido. ${ }^{38}$

\section{A abertura política}

Para além das disputas internas, o PC do B, no início da década de 1980, tentava sintonizar as suas propostas e atuação com a nova situação surgida com a abertura política. Nesse sentido, o ano de 1979 tem um significado importante. Apesar de 
defender a bandeira da redemocratização desde 1975, foi com a aprovação da Lei da Anistia que o caminho da luta pelo fim da Ditadura Militar, por meio da convocação de uma constituinte, ganhou força. Além disso, nesse momento começam a sair da prisão e voltar do exílio os seus dirigentes, o que deu novo impulso ao partido.

O PC do B, procurando diferenciar-se de outras forças políticas, enfatizava que a Anistia e a Abertura Política não eram dádivas de João Batista Figueiredo, e sim fruto de mobilizações que se espalhavam pelo país. Da mesma forma, a derrota definitiva da ditadura não aconteceria sem pressão popular. Nesse caminho, propunha a luta pela Constituinte conjugada com a liquidação do regime militar através da unificação dos movimentos populares de oposição. Para a realização de seu programa, o PC do B indicava a utilização de diversas formas de luta, particularmente a participação dentro do PMDB, visto como aglutinador das forças antiditatoriais. O partido deveria se diferenciar dentro da frente política com a sua proposta, mais radical do que a dos outros participantes, de um "Governo da Forças Democráticas e Populares e da Unidade Popular". 39

De acordo com proposta acima, o PC do B empenhou-se na campanha eleitoral de 1982, na qual foram disputados cargos para governos de estados e municípios, do Senado, da Câmara dos Deputados, das Assembléias Legislativas e Câmaras Municipais. Além disso, o Congresso eleito decidiria o futuro do país no Colégio Eleitoral em 1985. Dada a importância do pleito, o partido o apontava como um verdadeiro plebiscito político do regime. Nesse sentido, os comunistas deveriam participar ativamente da campanha para eleger os candidatos do PMDB, que teriam maiores chances de vitória contra o governo. ${ }^{40}$ No resultado final da eleição, a oposição conseguiu 59\% dos votos e maioria na Câmara dos Deputados; já no Senado, o partido governista teve a maioria. O PC do B elegeu os deputados federais Aurélio Peres, por São Paulo; Haroldo Lima, pela Bahia; Aldo Arantes, por Goiás; e José Luiz Guedes em Minas Gerais.

\section{O VI Congresso, a união partidária e a guerrilha do Araguaia}

A abertura dos trabalhos para o VI Congresso foi anunciada no início de 1982, e o conclave realizado entre o final desse ano e início de 1983. O objetivo central da reunião foi a discussão sobre "a linha política e sua aplicação, o funcionamento e o fortalecimento partidário". ${ }^{41}$ Os debates preparatórios não apresentaram novidades em 
relação à conduta que o partido vinha adotando desde 1980. Não houve qualquer manifestação de crítica ao informe político apresentado pelo Comitê Central, nem polêmicas sobre temas candentes. O maior significado do Congresso talvez tenha sido a demonstração de união dos militantes em torno da política partidária. ${ }^{42}$

Certamente a explicação para a forma como transcorreu o Congresso encontrase nos eventos ocorridos nos anos anteriores, que redundou na expulsão de inúmeros militantes. As discussões mais acaloradas e o questionamento mais profundo da linha partidária, conforme vimos acima, foram feitos durante a crise em que se envolveu o partido entre 1979 e 1982. A saída dos militantes pouco antes do Congresso parece ter arrefecido as hesitações que ainda pudessem existir em torno da linha política oficial.

No que diz respeito às conclusões do Congresso, pode-se destacar a proposta de derrubada da ditadura e a "conquista da mais ampla liberdade política" como centro da tática partidária. ${ }^{43}$ Com a derrubada do regime e o possível surgimento de um governo provisório, dever-se-ia colocar em pauta a convocação de uma Assembléia Constituinte e o desmantelamento de todo o aparato repressivo. O elemento essencial da tática partidária deveria ser a conquista das liberdades, uma vez que "em torno dessa questão mobilizam-se as forças que se opõem resolutamente à ditadura e à existência de fortes restrições aos direitos do povo". 44

Ao lado das questões relativas às suas propostas políticas, que foram reafirmadas no Congresso, a resolução fundamental do encontro diz respeito, mais uma vez, à guerrilha do Araguaia. Como vimos acima, a VII Conferência apontara o documento "Gloriosa Jornada de Luta" como ponto de partida para a elaboração de uma resolução definitiva sobre a problemática do significado da guerrilha. Nesse caminho, foi aprovado pelo VI Congresso o Estudo crítico acerca do princípio da violência revolucionária, documento que oficializa a interpretação do partido sobre a guerrilha. De uma maneira geral, o texto segue a idéia de que a guerrilha teve um papel essencialmente positivo, constituindo-se na "expressão mais avançada da resistência popular após o golpe militar de 1964". ${ }^{45}$ O informe sobre o Araguaia também admite que alguns erros foram cometidos pela guerrilha, os quais dizem respeito basicamente a questões pontuais. Na verdade, as observações sobre as falhas da guerrilha restringemse àquelas que já haviam sido feitas pelo próprio Ângelo Arroio no relatório que escrevera sobre a sua participação na luta e que serviu como base para a escrita do documento Gloriosa jornada de luta. 
A partir de meados dos anos 1980, as discussões sobre a guerrilha do Araguaia cessaram dentro do $\mathrm{PC}$ do $\mathrm{B}$ e, aos poucos, tornaram-se unânimes às interpretações da direção do partido. Esse processo pode ser acompanhado pelas sucessivas publicações sobre a guerrilha nas décadas de 1980 e 1990. Em todas as publicações, ela é exaltada como uma façanha histórica de luta contra a ditadura. Um exemplo particularmente marcante está na publicação comemorativa dos 30 anos do início da guerrilha em 2002. O livro, intitulado "Uma epopéia pela liberdade - Guerrilha do Araguaia 30 anos (19722002)", não faz menção de crítica, por menor que seja, a qualquer erro o qual possa ter sido cometido durante a guerrilha, o que significa dizer que não indica também que, nas duas décadas anteriores, houve importantes divergências internas a seu respeito.

O tema da guerrilha do Araguaia é, sem dúvida, o que ocupa maior destaque na construção da identidade partidária do PC do B. Hoje, pode-se afirmar que todos os militantes do partido se identificam com o episódio como o mais emblemático do caráter revolucionário e coerente da legenda, o que lhe confere grande força simbólica. Um exemplo marcante de tal significado foi o pedido feito, pouco antes de morrer, pelo dirigente mais importante do partido, João Amazonas. O velho líder e fundador do PC do B, que chegou a participar da preparação da guerrilha, pediu para que as cinzas de seu corpo fossem jogadas na região do Araguaia, o que foi feito no dia 21 de junho de 2002. Realizou-se uma cerimônia na cidade de Xambioá para lançar as suas cinzas, ao mesmo tempo em que se anunciou a construção de um memorial sobre a guerrilha na região. $^{46}$

\section{O PT e a CUT}

Desde o final dos anos 1970, com o início do processo de abertura política, o PC do $\mathrm{B}$ defendia a proposta de unidade de uma ampla frente política de combate à ditadura, postura essa que manteria na primeira metade dos anos 1980. Esse posicionamento marcou as suas relações com as forças de oposição que surgiram no país, sobretudo após a mudança da legislação eleitoral que extinguiu o bipartidarismo. $\mathrm{O}$ PC do B via na legislação uma manobra da ditadura militar para enfraquecer a oposição e insistia na necessidade da unidade da oposição em torno do PMDB. Quanto às outras forças de esquerda, o PC do B faria duras críticas. Sobre o Partido Democrático Trabalhista (PDT), liderado por Leonel Brizola, afirmava: “está ligado à socialdemocracia européia, em particular a alemã, e conta também com o beneplácito dos 
imperialistas ianques. É um agrupamento reformista, que reúne setores da burguesia e da classe média". ${ }^{47}$ O Partido Trabalhista Brasileiro (PTB) seria uma força pequena que se propunha a "servir abertamente de linha auxiliar do governo" ${ }^{48} \mathrm{O} \mathrm{PCB}$, por sua vez, tinha uma orientação de conciliação e de "direita". 49 Já o Partido dos Trabalhadores, certamente devido a sua importância política, merecia uma preocupação e combate por parte do PC do B, tanto em termos ideológicos quanto na atuação prática:

\begin{abstract}
O PT surge dentro da área proletária como agrupamento reformista com linguagem classista. Reflete, em certa medida, a aspiração dos trabalhadores de ter o seu próprio partido, distinto dos partidos da burguesia. No entanto, não é um partido proletário, sua ideologia não é proletária e seus objetivos não são fundamentalmente os da classe operária, isto é, a revolução proletária e o socialismo científico. Este partido, que atrai uma parcela da classe operária e também da classe média, conta com o apoio de vários sindicalistas, de um setor da igreja, das correntes trotsquistas, do chamado grupão de esquerda e de democratas antes ligados ao MDB. ${ }^{50}$
\end{abstract}

A preocupação do PC do B com a ascensão do PT apareceu de forma clara em um longo artigo escrito por João Amazonas, em meados de 1980, para a revista Princípios. O dirigente afirma que o PT, como principal representante da socialdemocracia no Brasil, tem como objetivo principal desviar o proletariado de sua luta revolucionária, impedir a sua unidade e dificultar o avanço na formação de sua consciência de classe: "tenta fazer sombra ao PC do Brasil, cuja autenticidade é negada pela cúpula dirigente desse agrupamento pretensamente proletário". ${ }^{51}$ Ainda em 1981, de forma ríspida, o PC do B afirma que o PT "surge com a reorganização partidária promovida pela ditadura, que veta de forma categórica a legalização do Partido Comunista do Brasil e de outras forças de esquerda, admitindo, porém, a criação de um partido daquele tipo" e que seria "significativo o fato de que, na época, havia empresários e gente do governo querendo criar um partido de trabalhadores". ${ }^{52}$

Desde cedo, o PC do B avaliou negativamente a atuação do PT. Assim, no início dos anos 1980, condenava os petista por romperem com a unidade popular em torno do PMDB, enfraquecendo a oposição aos militares. ${ }^{53}$ Questionava o PT por enfatizar a luta econômica e não se dedicar claramente ao combate à ditadura. ${ }^{54}$ Posicionou-se ainda criticamente quando o partido de Lula não colocou de forma clara em seu programa a bandeira pela convocação de uma Constituinte. ${ }^{55}$

As críticas ao Partido dos Trabalhadores aumentaram após a derrota da Emenda Dante de Oliveira, quando o PT se recusou a participar da votação no Colégio Eleitoral e anunciou a imediata oposição ao governo de Tancredo Neves e, em seguida, de José Sarney. O PC do B avaliava que o PT, beneficiado pelo apoio que recebera pela 
participação na campanha pelas eleições diretas, acabara por se isolar com sua prática sectária de oposição a Tancredo. Afirmava, ainda, que a política de oposição até o momento voltada contra os militares, se continuasse após a eleição, como anunciaram os petistas, iria "contrapor-se a um governo democrático" e "servir aos interesses da direita, do malufismo sobretudo". 56

As divergências do PC do B com o PT, ao mesmo tempo em que apareciam na cena política nacional, também estavam presentes na atuação sindical. Vale lembrar que o movimento sindical brasileiro ganhou grande impulso com as greves de 1978, 1979 e 1980, acontecidas no estado de São Paulo, em plena ditadura militar. Com tal crescimento, as lideranças sindicais eram unânimes na proposta de buscar a unificação do movimento sindical, de modo que o sindicalismo se fortalecesse e adquirisse uma coordenação nacional.

Nesse processo, aparecem dois blocos de forças. De um lado, os sindicalistas "autênticos", dos quais fazem parte os metalúrgicos do $\mathrm{ABC}$ e as "Oposições sindicais", formando a base do chamado novo sindicalismo. De outro lado, havia a Unidade Sindical, que era composta por lideranças tradicionais do sindicalismo, inclusive aqueles chamados de "pelegos", e militantes de organizações da esquerda comunista, como o PC do B, o PCB e o Movimento Revolucionário 8 de Outubro (MR8). ${ }^{57}$ Estes dois blocos estiveram na disputa da criação das centrais sindicais brasileiras no início dos anos 1980: "o bloco combativo considerava a estratégia da Unidade Sindical como negocista, conciliadora e reformista. A Unidade Sindical, por sua vez, avaliava a estratégia do outro setor como sendo esquerdista e desestabilizadora" ${ }^{58}$ Essa correlação de forças marcaria atuação do PC do B no movimento sindical na primeira metade dos anos 1980.

O primeiro e principal embate entre as duas forças deu-se durante a realização da I Conferência Nacional da Classe Trabalhadora (I Conclat), que foi realizada em 1981, na Praia Grande. No encontro, foi eleita uma comissão coordenadora da Central Única dos Trabalhadores (a Comissão Pró-CUT), que deveria centralizar a luta dos trabalhadores e organizar a II Conclat, durante a qual se deveria fundar a CUT. Para o PC do B, a realização da Conclat foi uma grande vitória dos trabalhadores, da cidade e do campo, na luta contra a ditadura e pela unidade do movimento sindical em torno de uma central única. ${ }^{59}$ Entretanto a criação da CUT não seria tarefa fácil. Segundo o PC do $\mathrm{B}$, demonstrando as divergências que havia no interior da Conclat, 
a Comissão Organizadora da CUT, indicada à última hora na CONCLAT, não representa o verdadeiro anseio das massas. Sua composição majoritária é de gente que, no fundo, se opõe à central sindical única. Nela predominam pelegos, revisionistas, elementos favoráveis ao pluralismo. Eles se uniram na votação dos nomes, em plenário, para barrar o acesso dos partidários decididos da CUT, em especial dos marxistas-leninistas, apesar da expressiva representação que tinham na CONCLAT. Todavia, queira ou não o governo, os pelegos, os divisionistas e os oportunistas, é possível vencer os obstáculos e fundar uma organização nacional capaz de coordenar, de modo independente, os movimentos sindicais e populares, dando-lhes mais força, desenvolvendo solidariedade e o espírito de classe. ${ }^{60}$

A Unidade Sindical alegou que 1982, por ser um ano eleitoral, não era viável para realização da II Conclat e, logo, a fundação da CUT. O evento foi remarcado para agosto de 1983. Aproximando-se a nova data, mais uma vez a Unidade Sindical procurou adiar a sua realização, alegando, dessa vez, as dificuldades colocadas pelas divergências a respeito da representação dos delegados que deveriam participar. O setor combativo realizou o encontro em São Bernardo do Campo e fundou a CUT. Os representantes da Unidade Sindical, com importante participação do PC do B, realizaram um encontro em novembro do mesmo ano. Decidiram por não criar uma segunda central sindical, sob a alegação de que isso oficializaria a divisão no sindicalismo brasileiro. Em lugar de uma central, criou-se a Coordenação Nacional da Classe Trabalhadora (Conclat). ${ }^{61}$ Somente em 1986 a Conclat resolveu tornar-se uma central, nascendo, então, a Central Geral dos Trabalhadores (CGT).

Durante todo esse processo, o PC do B defendia a unidade sindical, mesmo após a criação de CUT, que consumava a cisão. No interior da Conclat, posicionava-se contra a sua transformação em uma central. Ao mesmo tempo, na primeira metade dos anos 1980, o partido sempre responsabilizou a CUT pela divisão sindical brasileira. Afirmava, por exemplo, que esta central, "a partir de uma visão pluralista e paralelista do movimento sindical, reduziu-se na prática à ação de um partido político e não de uma entidade sindical". Além disso, ao se identificar política e ideologicamente com as posições petistas, “desempenha um papel desagregador da unidade sindical”. ${ }^{62}$

\section{Diretas já! Colégio eleitoral e o governo Sarney}

Aproveitando-se do clima de semiliberdade pelo qual passava o país, ${ }^{63}$ o PC do B constituiu uma "Comissão Nacional Pela Legalidade", que acabou servindo como fachada legal para a atuação partidária nos estertores do regime militar. A comissão participou de diversos movimentos pela democratização, ao mesmo tempo em que reclamava a legalização. Entre os eventos fundamentais do período, não só para PC do 
B, mas para a trajetória recente do país, está a campanha pelas eleições diretas para presidente no final do governo do general João Batista Figueiredo, as Diretas Já! ${ }^{64}$

A campanha foi lançada pelo PMDB em abril de 1983 e abraçada mais radicalmente pelo Partido dos Trabalhadores, que foi uma força fundamental para o crescimento do movimento. O primeiro comício foi organizado pelo PT em novembro de 1983, próximo ao Estádio do Pacaembu, em São Paulo, com a participação de inúmeros políticos, intelectuais e artistas. Os partidos de oposição, como o PMDB e o PDT, apoiaram sem grande envolvimento. Entretanto o êxito do encontro e o crescimento vertiginoso da campanha em todo o país acabaram por envolver toda a oposição.

O PC do B engajou-se tardiamente na campanha. Em sua análise, o país vivia um clima de crise política institucional e dificilmente o governo Figueiredo resistiria até 1985. Nesse caminho, mesmo concordando que a campanha pelas diretas fosse importante, questionava se ela deveria ser o principal objetivo. ${ }^{65}$ Propugnava a mobilização popular para a derrubada da ditadura e a formação de um governo provisório, consubstanciado na palavra de ordem "Fora Figueiredo, Abaixo o regime militar! Por um Governo Provisório, Patriótico, Democrático e Popular". Em uma reunião realizada em São Paulo, explicava o partido a sua posição:

\footnotetext{
Nosso partido tem levantado esta bandeira [das eleições diretas]. Hoje, com o desenrolar dos acontecimentos, percebemos a seguinte questão: de um lado a crise se aprofunda rapidamente; de outro, a eleição para presidente só ocorrerá em 1985, ou seja, daqui a dois anos. Será que o problema mais candente que se coloca hoje é o de se concentrar na luta pelas eleições diretas? Daqui até a realização dessas eleições o Brasil continuará governado por Figueiredo? Estamos vendo, dado o agravamento da crise, dado o sentimento da massa, que a questão da eleição direta não é a saída como bandeira mais imediata, como questão chave que o movimento está colocando. ${ }^{66}$
}

Com o desenrolar e intensificação da campanha, que logo ganhou adesão massiva, o PC do B engajou-se na luta pelas diretas e modificou o seu posicionamento. A partir de fevereiro de 1984, passou a apontar a campanha pelas diretas como "a forma concreta, prática, imediata de pôr fim ao governo dos militares". ${ }^{67}$ Apesar de toda a mobilização popular, no dia 25 de abril de 1984 a emenda Dante de Oliveira, que propunha a eleição direta para presidente da República, foi derrotada no Congresso Nacional. A eleição seria indireta, com votação no Colégio Eleitoral, e aconteceria no dia 15 de janeiro de 1985. 
A derrota da Emenda Dante de Oliveira causou profundo desânimo nas forças que lutaram pelas diretas, levando-as à desmobilização. Alguns, como o Partido dos Trabalhadores, rechaçaram o resultado da votação e colocaram-se contra a participação na eleição indireta. Já o PC do B propunha que se mantivesse a mobilização popular, pois, mesmo com a derrota da emenda Dante de Oliveira, o governo saíra enfraquecido. ${ }^{68} \mathrm{O}$ partido denunciava ainda àqueles que procuram esvaziar o caráter popular da luta, passando às negociações de cúpula. ${ }^{69}$

Depois de muitas negociações entre os setores de oposição e crise na base governista, foram definidos os candidatos que concorreriam à presidência. De um lado, Tancredo Neves, apoiado pelo PMDB, setores do PDS e outros partidos de oposição, com exceção do PT, que se recusou a participar do Colégio Eleitoral. De outro lado, Paulo Maluf, apoiado pelo PDS. No dia 15 de janeiro, Tancredo Neves venceu a eleição. Pouco antes da posse, entretanto, foi submetido a uma cirurgia, vindo a falecer no dia 21 de abril. Assumiu a presidência o seu vice, José Sarney, dando início ao período da Nova República.

Logo após a vitória de Tancredo, o PC do B fez uma análise positiva do resultado. Em primeiro lugar, destacou que a eleição, ainda que no Colégio Eleitoral, colocara fim ao Regime Militar, o que não teria sido possível sem a mobilização popular. Naquela situação, a tática partidária deveria partir de uma política ampla, junto com as mais variadas correntes de opinião, voltada para a mobilização de massa "no sentido de garantir as mudanças reclamadas pelo povo, vencendo as resistências dos setores conservadores do governo", ${ }^{70}$

Com a chegada de José Sarney à presidência, o partido continuou a política de frente ampla para defender o aprofundamento das liberdades democráticas. Nesse sentido, desde o princípio, apoiou o governo Sarney, na medida em que este representava avanços no processo de redemocratização. Por exemplo, o novo presidente apoiou a legalização de todos os partidos, inclusive os comunistas; admitiu o direito de greve aos trabalhadores; respeitou o Congresso nacional e os Direitos Humanos e, por fim, esteve engajado na convocação da Constituinte. ${ }^{71}$ Ainda sobre o governo Sarney, o partido afirmava que era necessário reconhecer aspectos positivos e negativos em sua atuação. Entretanto uma oposição sistemática estava descartada, uma vez que isso facilitaria o jogo da direita. ${ }^{72}$

Em 1985, o PC do B conseguiu a sua legalização junto ao Tribunal Superior Eleitoral. Com a legalidade em mãos, participou da campanha eleitoral de 1986, pela 
primeira vez com os seus candidatos inscritos na própria legenda. ${ }^{73}$ A campanha e o momento político estavam marcados pelo debate em torno da Constituinte, tema ao qual o partido dedicou toda a sua atenção. ${ }^{74}$ Para o PC do B, somente a nova constituição colocaria fim a todo aparato do regime militar e possibilitaria a conquista de direitos à população. Entretanto caberia à oposição se unir contra as forças conservadoras que se posicionariam hostilmente à conquista desses direitos. Nesse caminho, o PC do B mantém a sua proposta de ampla frente política até o final da Constituinte.

$\mathrm{Na}$ segunda metade dos anos 1980, o partido reorientaria a sua atuação na política nacional. No início de 1987, abandonou o apoio crítico ao governo Sarney, passando à oposição. Em linhas gerais, o PC do B avaliava que o governo passara completamente para o campo conservador. No ano seguinte, realiza o seu VII Congresso, no qual reafirmou o seu deslocamento à esquerda na cena política nacional, o que se traduz na palavra de ordem Fora Sarney, Diretas 88! No mesmo caminho, ele redefiniu a sua política de aliança no plano político e sindical. Ainda que continuasse criticando o PT, representante da "social-democracia que está a serviço do capitalismo", afirmava que seria um "erro tático atacar o PT em bloco. Nele militam homens e mulheres progressistas, contingentes proletários dispostos a defender seus interesses e que se mostram subjetivamente a favor do socialismo". 75

A mudança na orientação política do PC do B em meados dos anos 1980 teve desdobramentos importantes na política partidária nas décadas seguintes. Por exemplo, levou o PC do B a integrar a Frente Brasil Popular, coligação que apoiou a candidatura de Luiz Inácio Lula da Silva à presidência da República em 1989. Aliança que se prolongaria nas eleições de 1994, 1998 e 2002, quando o candidato do PT foi eleito presidente. Ao mesmo tempo, no plano sindical, o partido abandonou definitivamente a CGT, integrando-se à CUT. As questões relativas ao final dos anos 1980, entretanto, não fazem parte das preocupações deste artigo, e delas tratarei em trabalhos futuros ${ }^{76}$. O que se pretendeu aqui foi mostrar a profunda transformação pela qual passou a política do PC do B entre os anos 1970 e 1980. E que, para essa mudança, pesaram tanto as discussões e divergências internas, quanto as modificações da política nacional, que acabara de ver o fim do período militar e a volta a democracia após 30 anos de ditadura. 


\section{REFERÊNCIAS BIBLIOGRÁFICAS:}

AMAZONAS, J. A social-democracia, instrumento do capitalismo. Princípios, junho de 1981.

A atualidade da Assembléia Constituinte. Princípios, abril de 1985.

BUONICORE, A. C. A história do PC do B entre 1979 e 1985. mimeo.

CABRAL, P. Xambioá - Guerrilha do Araguaia. São Paulo: Record, 1993.

CAMPOS FILHOS, R. P. Guerrilha do Araguaia. A esquerda em armas. Goiânia: Editora da UFG, 1997.

DIAS, R. Sob o signo da revolução brasileira: a experiência da Ação Popular no Paraná (1962-1973). Assis, 1997. Dissertação (Mestrado em História) - FCL, UNESP/Assis, 1997.

DÓRIA, P. et al. A guerrilha do Araguaia. São Paulo: Alfa-Ômega, 1978.

DREYFUS, M. PCF. Crises et dissidences. De 1920 à nos jours. Paris: Editions Complexe, 1990.

GALDINO, A. C. O PC do Brasil e o movimento de luta armada nos anos 60. Campinas, 1994.

LIMA, H., ARANTES, A. História da Ação Popular: da JUC ao PC do B. São Paulo: Alfa-Omega, 1984.

MORAIS, T. \& SILVA, E. Operação Araguaia: os arquivos secretos da guerrilha. São Paulo: Geração Editorial, 2005.

MOURA, C. Diário da guerrilha do Araguaia. São Paulo: Alfa-Omega, 1979.

OLIVEIRA JR., Franklin. Paixão e revolução: capítulos sobre a história da AP. Recife, 2000. Tese (Doutorado em História) - DH, UFPE.

PARTIDO COMUNISTA DO BRASIL. O PT: um partido falsamente proletário (1981). In: CARONE, E. O movimento Operário no Brasil (1964-1984). São Paulo: DIFEL, 1984.

. A política revolucionária do $P C$ do $B$. Informes ao $7^{\circ}$ Congresso realizado em maio de 1988. 2. ed. São Paulo: Anita Garibaldi, 1989.

. Guerrilha do Araguaia. São Paulo: Anita Garibaldi, 1996.

. Em defesa dos trabalhadores e do povo brasileiro. São Paulo: Anita Garibaldi, 2000, p. 349.

. Uma epopéia de liberdade. Guerrilha do Araguaia 30 anos (1972-2002). São Paulo: Anita Garibaldi, 2002. 
POMAR, Valter Ventura da Rocha. Comunistas do Brasil. Interpretações sobre a cisão.

São Paulo, 2000. Dissertação (Mestrado em História) - FFLCH, USP.

POMAR, W. Araguaia, o Partido e a Guerrilha. São Paulo: Global, 1980.

PORTELA, F. A Guerra de guerrilhas no Brasil. São Paulo: Global, 1979.

RIDENTI, M. O impacto da crise do socialismo no Partido Comunista do Brasil, 19881992. Perspectivas, São Paulo, n. 17-18, p. 75-94, 1994/1995.

Ação Popular: cristianismo e marxismo. In: RIDENTI, M., REIS FILHO, D.

A. (orgs.). História do marxismo no Brasil. Campinas: Editora da UNICAMP, 2002. v.

V, p. 213-282.

SÁ, G. Relato de um Guerrilheiro. São Paulo: Anita Garibaldi, 1990.

SALES, J. R. Partido Comunista do Brasil (PC do B): definições ideológicas e trajetória política. In: REIS FILHO, D. A., RIDENTI, M. (orgs.). História do marxismo no Brasil, vol. VI. Campinas: Editora da UNICAMP, 2007 (no prelo).

Partido Comunista do Brasil - PC do B: propostas teóricas e prática política

- 1962-1976. Campinas, 2000. Dissertação (Mestrado em História) - IFCH, UNICAMP.

SANTANA, M. A. Trabalhadores em movimento: o sindicalismo brasileiro nos anos 1980-1990. In: FERREIRA, J., DELGADO, L. de A. N. (orgs.). O Brasil republicano, vol IV. Rio de Janeiro: Civilização Brasileira, 2003.

SANTOS, A. C. Ação entre amigos: história e militância do PC do B em Salvador (1965-1973). Salvador, 2004. Dissertação (Mestrado em História) - DH, UFBA.

SILVA, A. O. da. Os comunistas diante do muro: o marxismo-leninismo entre a negação e a afirmação da tradição stalinista. Diálogos, Maringá, v. 3, n. 3, p. 263-290, 1999.

Sales, Jean Rodrigues. Between the closing and the opening: the path of the "PC do B" from the Araguaia guerrilla to the New Republic (1974-1985). História, São Paulo, v. 26, n. 2, p. 340-365, 2007.

Abstract: The objective of the present article is to discuss the history of the Brazilian Communist Party ( $\mathrm{PC}$ do $\mathrm{B}$ ) during the period that stretches from the Araguaia guerrilla in 1974 to the consolidation of the New Brazilian Republic with José Sarney elected President of the Republic in 1985. Our analysis focuses on understanding the process of change of the political line of the party as the latter seeks to adapt to the process of democratization Brazil underwent at that time. 
Keywords: Brazilian Communist Party (PC do B), Military Dictatorship, New Republic, Democratization.

Artigo recebido em 06/2007. Aprovado em 10/2007.

\title{
NOTAS:
}

\begin{abstract}
${ }^{1}$ Este artigo é o primeiro resultado de uma pesquisa de pós-doutorado, desenvolvida na USP, financiada pela Fapesp e supervisionada pela Prof. Dra. Maria Aparecida de Aquino. O objetivo da pesquisa é tratar da história do PC do B no período compreendido entre o final da guerrilha do Araguaia, em 1974, e a chegada do partido ao governo Federal, em 2002, juntamente com a coligação que apoiou a candidatura de Luiz Inácio Lula da Silva. Neste artigo, discuto a história partidária até meados dos anos 1980, com a consolidação da Nova República.

* Pós-doutorando no Departamento de História da Faculdade de Filosofia, Letras e Ciências Humanas da Universidade de São Paulo - USP. Bolsista da FAPESP. E-mail: jeanrodrigues5@yahoo.com.br.

${ }^{3}$ Discuti essa questão em trabalhos anteriores: Sales in Reis \& Ridenti, 2007 (no prelo). Sales, 2000.

${ }^{4}$ Além dos trabalhos citados acima, temos como produção acadêmica sobre o assunto: Galdino, 1994; Pomar, 2000; Santos, 2004. Campos Filhos, 1997. Para o período dos anos 1980 e 1990, os trabalhos publicados foram os seguintes: Ridenti, 1994/1995 e Silva, 1999.

${ }^{5}$ Não faz parte dos objetivos deste artigo tratar dos eventos relativos à guerrilha do Araguaia propriamente ditos, mas sim do significado e das conseqüências dessa experiência para a história partidária. A respeito da história da guerrilha, ver: Pomar, 1980; Portela, 1979; Dória, 1978; Campos Filhos, 1997. Do próprio partido, ver: Partido Comunista do Brasil, 1996; Partido Comunista do Brasil, 2002. Foi também publicado o diário dos guerrilheiros, ver: Moura, 1979. Ver ainda o relato, em forma de memórias, de um dos participantes: Sá, 1990, e uma versão romanceada dos acontecimentos, Cabral,
\end{abstract} 1993. Mais recentemente foi publicado o livro dos jornalistas Morais \& Silva, 2005.

6 "Invencível bandeira de luta". A classe operária, abril de 1976.

${ }^{7}$ POMAR, W., 1980, p. 157-165.

${ }^{8}$ Ibidem, p. 278.

${ }^{9}$ Pedro Pomar foi militante do Partido Comunista Brasileiro (PCB) desde os anos 1940. Em 1962 esteve entre aqueles que reorganizaram o $\mathrm{PCdoB}$, tornando-se um de seus principais líderes.

${ }^{10}$ Ibidem, p. 293.

${ }^{11}$ Ibidem, p. 50-55 e Gorender, 1998, p. 233-243.

${ }^{12}$ Não caberia neste artigo tratar da história da Ação Popular. O objetivo aqui é destacar a importância da incorporação da AP na trajetória do PC do B. Especificamente sobre a história da AP, ver: Ridenti in: Ridenti, \& Reis Filho, 2002, v. V, p. 213-282 e Dias, 1997.

${ }^{13}$ Análise crítica do processo de incorporação de segmentos que se desligaram de outras organizações e da Ação Popular. In: Partido Comunista o Brasil, 2000, p. 349.

${ }_{15}^{14}$ A esse respeito ver Oliveira Jr., 2000.

${ }^{15}$ Informações sobre a incorporação ao PC do B foram-me fornecidas em três entrevistas com membros da AP-ML, que se incorporaram ao PC do B: Aldo Arantes, Haroldo Lima e Ronald de Freitas.

${ }^{16}$ Lima, \& Arantes, 1984.

${ }^{17}$ Sobre as interpretações a respeito da incorporação da AP ao PC do B, ver: DIAS, R.. A história da Ação Popular na perspectiva do PC do B: uma análise da obra de Haroldo Lima e Aldo Arantes sobre a história da AP. Diálogos, Maringá, v. 10, n. 1, p. 143-175, 2006.

${ }^{18}$ Ver, a este respeito, o artigo: "Relevante fato político". A classe operária, janeiro de 1975.

19 "Derrotar a ditadura na farsa eleitoral". A classe operária, outubro de 1976.

20 "Anistia ampla, irrestrita, às vítimas da ditadura". A classe operária, abril de 1978. Ver ainda a esse respeito: "Ir sempre adiante no combate à Ditadura". A classe operária, setembro/outubro de 1977 e "Congresso pela anistia geral e irrestrita". A classe operária, novembro de 1978.

21 "A bandeira de luta do Araguaia". A classe operária, janeiro de 1975.

${ }^{22} \mathrm{O}$ "Manifesto à Nação" foi publicado no jornal A classe operária, em março-abril de $1979 \mathrm{e}$, em linhas gerais, delineia as propostas que foram seguidas na VII Conferência. 
23 "Resoluções da VII Conferência do Partido Comunista do Brasil". In: Partido Comunista do Brasil, 2000, p. 267-268.

${ }^{24}$ Ibidem, p. 268.

${ }^{25}$ Dreyfus, 1990, passim.

${ }^{26}$ Desde 1973, por motivos de segurança, havia em São Paulo duas “Estruturas” Regionais, a 1 e a 2.

${ }^{27}$ Secretariado regional da Bahia. "Alguns aspectos de nosso funcionamento partidário - questões para debate". Dezembro de 1979. Este documento, bem como muitos outros envolvidos na polêmica, pode ser visto no Fundo Duarte Pereira Pacheco (FDPP) no Arquivo Edgard Leuenroth (AEL), na Universidade Estadual de Campinas (UNICAMP), caixa 4.

${ }^{28}$ Cabe lembrar que o PC do B, desde o início dos anos 1960, foi aliado dos chineses e defensor fervoroso das idéias de Mao Tse-tung. Além disso, entre as organizações brasileiras que se definiam como maoístas, o partido recebia um tratamento preferencial do Partido Comunista Chinês (PCCh). A divergência e a cisão, entre o PC do B e o PCCh, acontecem apenas em 1978, o que pode ser acompanhado no documento "Breve histórico das divergências com o PC da China". A classe operária, dezembro de 1978.

${ }^{29}$ Secretariado Regional da Bahia. "Sobre nossos erros e divergências: sua discussão e correção". Janeiro de 1980. (FDPP, Caixa 4).

30 "Informe do Comitê Central do Partido Comunista do Brasil", março de 1980, passim.

31 "Resoluções da sessão plenária do Comitê Central". A classe operária, março de 1980.

${ }^{32}$ Ver as medidas tomadas pelo C. C. contra os Comitês de São Paulo e Bahia na edição número 144 do jornal A classe operária, de julho-agosto de 1980.

${ }^{33}$ Comitê Regional Estrutura 1 de São Paulo. “Aos camaradas e amigos do partido”, setembro de 1980.

${ }^{34}$ A "Carta de Pomar" foi publicada no número 1991 do jornal Movimento.

${ }^{35}$ Sobre as expulsões, ver as edições 142-146 do jornal A classe Operária, de março de 1980 a março de 1981.

${ }^{36}$ Sobre a participação do PC do B em movimentos sociais no período, ver: Buonicore, mimeo. (O texto será publicado em breve em um livro organizado pelo PC do B sobre a sua história.)

${ }^{37}$ Ver a este respeito entrevistas realizadas pelo autor com José Renato Rabelo e Sérgio Miranda, à disposição no AEL.

${ }^{38}$ Um exemplo desta visão pode ser visto em uma entrevista realizada pelo autor com Ozéas Duarte, à disposição no AEL.

${ }^{39}$ Sobre as propostas políticas do partido no início da década de 1980 , ver o seguinte documento assinado pelo Comitê Central: "Situação brasileira, tarefas e propostas políticas do P.C. do Brasil". A classe operária, maio-junho de 1980, p. 1-16.

40 "A campanha eleitoral é uma das tarefas principais dos comunistas". A classe operária, junho-julho de 1982.

41 "Por um Congresso de unidade e fortalecimento do partido". A classe operária, fevereiro de 1982.

${ }^{42}$ Sobre o clima que reinou na preparação do Congresso, ver a Tribuna de Debates do Congresso, na qual não aparece qualquer polêmica sobre a política partidária. Baseei-me ainda em entrevista que realizei com Augusto Cezar Buonicore, membro do Comitê Central do PC do B.

43 “Informe político ao VI Congresso do PC do B”. In: Partido Comunista do Brasil, p. 302.

${ }^{44}$ Ibidem, p. 303.

45 Ibidem, p. 309.

${ }^{46}$ Sobre a relação entre memória e identidade partidária, ver: LAVABRE, M. C. Le fil rouge. Sociologie de la mémoire communiste. Paris: Presse de La Fondation Nationale des Sciences Politiques, 1994. A autora discute a utilização do passado por parte dos comunistas franceses no momento em que reconstituem a sua história. Ela demonstra que há uma articulação entre a história coletiva, os itinerários individuais dos militantes, a história contada pelo partido e as lembranças evocadas pelos militantes, conformando a identidade partidária.

47 "Situação brasileira, tarefas e propostas políticas do P. C. do Brasil". A classe operária, maio-junho de 1980.

${ }^{48}$ Ibidem.

49 Ibidem.

${ }^{50}$ Ibidem.

${ }^{51}$ Amazonas, 1981.

52 Partido Comunista do Brasil, 1984, p. 86.

53 “A classe operária e os partidos”. Tribuna da Luta Operária, 23 de fevereiro a 7 de março de 1980.

54 “Qual é a proposta do PT?" Tribuna da Luta Operária, 5 a 19 de março de 1980.

55 "PT rejeita constituinte". Tribuna da Luta Operária, 14 a 26 de junho de 1980.

56 “A posição dos comunistas em face da nova situação política”. A classe operária, março-abril de 1985. 
${ }_{57}^{57}$ Santana in Ferreira \& Delgado, 2003, p. 289-290.

${ }^{58}$ Ibidem, p. 291.

59 “A voz dos operários e camponeses na Conclat”. A classe operária, agosto-setembro de 1981.

${ }^{60}$ Ibidem.

${ }^{61}$ SANTANA, Marco Aurélio, 2003, p. 293.

62 "Lutas pela unidade do movimento sindical". A classe operária, março-abril de 1985.

${ }^{63}$ Não esqueçamos que até o final do governo Figueiredo os órgãos de repressão ainda estavam em atuação. Basta lembrar que, no mesmo ano de 1983, no qual o PC do B realizou, de forma clandestina, o seu Congresso, os dirigentes do PCB foram surpreendidos em seu Congresso, que foi organizado legalmente, e dezenas deles foram presos.

${ }^{64}$ Informações sobre a campanha das diretas podem ser encontradas em RODRIGUES, A. T. Diretas já! O grito preso na garganta. São Paulo: Fundação Perseu Abramo, 2003. (Coleção História do Povo Brasileiro).

${ }^{65}$ Ver, a este respeito, “Eleições Diretas Já!”. A classe operária, outubro de 1983.

${ }^{66}$ Apud Buonicre, mimeo.

${ }^{67}$ Ibidem.

68 "Reforçar a unidade alcançada e intensificar a luta". A classe operária, maio-junho de 1984.

69 "Mobilização popular e democrática para vencer as forças reacionárias" (Nota do C. C. publicada no jornal A classe operária, maio-junho de 1984).

70 "O PC do B na transição democrática". A classe operária, março-abril de 1985.

71 "Reuniu-se a direção Nacional do PC do B: uma segura orientação para novas batalhas". A classe operária, dezembro de 1985/janeiro de 1986.

72 "O PC do B face ao governo e à situação do país". A classe operária, março de 1986.

73 "Sobre a campanha eleitoral de 1986". A classe operária, março de 1986.

${ }^{74}$ Amazonas, 1985.

${ }_{76}^{75}$ Partido Comunista do Brasil, 1989, p. 41-42.

${ }^{76}$ Como apontei anteriormente, este artigo é o primeiro resultado de uma pesquisa de pós-doutorado que prevê a publicação de um segundo texto, no qual tratarei da aliança do PCdoB com o PT desde 1989 até 2002. Discutirei ainda, no desdobramento desta pesquisa, outros temas importantes da história partidária nas décadas de 1980 e 1990 , como a realização do $7^{\circ}$ e $8^{\circ}$ Congressos do partido, a crise aberta com o fim do socialismo real, o impeachment de Fernando Collor de Mello, concluindo com a análise chegada do partido à presidência da república, em 2002, juntamente com o PT. 